\title{
La imagen de la virtud doméstica en la obra de Van Gogh
}

\author{
Covadonga López de Prado Mistral \\ Museu de Bellas Artes da Coruña
}

PALABRAS CLAVE: Iconografía/ Pintura Postimpresionista/ Van Gogh

\section{RESUMEN}

En este articulo se pretende poner de manifiesto la influencia que ejercieron en Van Gogh los pintores holandeses del siglo XVII, una infuencia que se concreta de forma especialmente intensa en la imagen de la mujer en el hogar que para el pintor holandés se convierte a la vez, en un icono y en el ideal al que aspira para alcanzar la felicidad. Aunque después del primer periodo, en el que se centra este trabajo, se va desprendiendo de las influencias formales de la escuela barroca holandesa, ese modelo femenino de "la virtud domestica" permanecerá a lo largo de toda su obra sintetizándose finalmente en La Berceuse.

ABSTRACT

In this article, we would like to show the influence of the 17th Century Dutch painters on Vincent Van Gogh. This infuence is specially reflected in the figure of the woman at home. Besides, for Van Gogh, this figure turns into an icon and an ideal he seeks in order to reach hapiness. After the first period, which is the focus of this article, Van Gogh. gradually gets rid of the formal influences of the Dutch barrock school. Nevetheless, this womanly figure of "domestic virtue" will remain all through his work and eventually will be summarized in La Berceuse.

Analizar la imagen de la mujer que Van Gogh refleja en sus primeras obras supone tener en cuenta múltiples y complejos factores $\mathrm{y}$, como siempre que se tratan temas de esta índole, caminar sobre un terreno muy resbaladizo.

En primer lugar es necesario considerar hasta qué punto el artista holandés se impregnó o permaneció al margen de las ideas finiseculares que sobre la condición femenina eran difundidas por los filósofos, científicos y pseudo-científicos de moda que arraigaron en los ambientes artísticos y entre aquellos círculos snobs y decadentes que se consideraban la esencia de la modernidad.

El entorno familiar, sus creencias religiosas, la educación e inclinaciones lite-

\footnotetext{
* LÓPEZ DE PRADO, Covadonga.: "La imagen de la virtud doméstica en la obra de Van Gogh", Boletín de Arte $\mathrm{n}^{\circ} 28$, Departamento de Historia del Arte, Universidad de Málaga, 2007, págs. 327- 363.
} 
rarias, la tradición artística sobre la que construyó su estilo personal, sus vivencias y aspiraciones más íntimas así como los contactos con los ambientes artísticos e intelectuales del momento, son en última instancia los factores que nos van a permitir reconstruir su posición en relación con la condición femenina.

El repertorio de asuntos tratados por Van Gogh a lo largo de toda su producción artística donde la mujer asume un papel protagonista es muy limitado, a pesar del gran número de dibujos y óleos que lo constituyen. Básicamente nos encontramos con los siguientes temas y sus variaciones: retratos, escenas domésticas con un registro muy reducido, campesinas y la maternidad.

\section{LA CONDICIÓN FEMENINA EN LA PINTURA FINISECULAR EUROPEA.}

El desarrollo del capitalismo, la industrialización y la moral burguesa transformó el viejo modelo familiar con unidades autosuficientes en donde hombres y mujeres trabajaban juntos. El ámbito del trabajo fuera del hogar será exclusivo del hombre, especialmente entre los miembros de la clase media y alta mientras las mujeres quedan cada vez más relegadas a la esfera doméstica. Se trata de un modelo de sociedad que había comenzado a desarrollarse en la Holanda precapitalista del 600 donde se impuso entonces el culto a la domesticidad.

Sin embargo, en ese mundo en el que triunfa el sistema mercantilista y precapitalista dominado por la rígida moral calvinista, el prototipo de mujer objeto no tenía cabida: enclaustrada en los limites del hogar, debía ser modelo de humildad, honestidad y diligencia. Dentro de este ámbito donde el concepto de laboriosidad adquiere rango de principio religioso, no podía concebirse el culto a la mujer ociosa. La mujer, aunque limitada al entorno doméstico, tenía la obligación de ser útil, no un mero adorno del marido.

En el siglo XIX confluirán toda una serie de factores que harán que junto a este modelo de virtud doméstica, surjan otros prototipos femeninos bastante más sofisticados y con fuertes implicaciones de naturaleza sexual que incluso tendrán más éxito en el arte y la literatura finisecular, y de forma muy especial en los ambientes modernistas, simbolistas y decadentes.

El movimiento virulentamente antifemenino que se extiende a lo largo del siglo XIX tiene, como veremos de forma muy resumida, un importante soporte no solo ideológico sino incluso "científico".

La difusión de los resultados de las investigaciones llevadas a cabo entre los años 1860 y 1870 sobre la sexualidad femenina, hasta entonces ignorada, constituyeron un fuerte revulsivo: el reconocimiento de la existencia de una vida sexual de la mujer al margen de la procreación provocará un sentimiento de atracción y rechazo, pero sobre todo acrecentará los temores e inseguridades en el varón, que no está 


\section{Q: artículos La imagen de la virtud doméstica en la obra de Van Gogh}

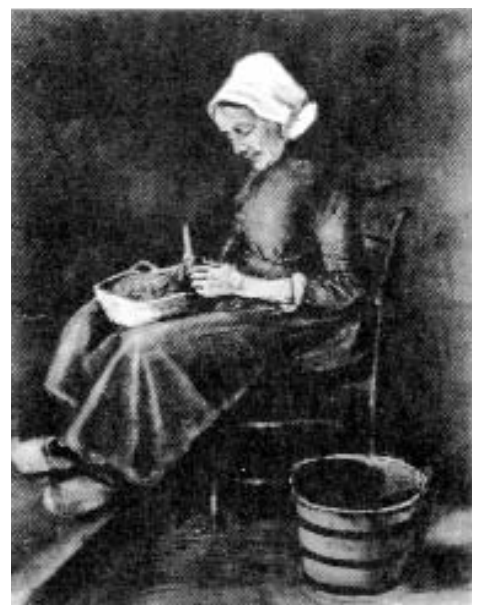

1. Mujer pelando patatas (1881) Otterlo, Rijksmuseum Kröller-Müller.

preparado para poder asumir esa nueva evidencia. En la imaginación de estos jóvenes, la mujer que no se ajuste al modelo del ser asexuado y dócil que la primera mitad del siglo había elevado a los altares del hogar burgués, se convertirá en una criatura primitiva, esclava de sus instintos, un ser de naturaleza perversa que, incapaz de someterse a las normas del mundo civilizado y del progreso, pretende arrastrar al hombre por el camino de la degeneración y de los instintos.

Tanto Darwin como Schopenhauer, dos personajes que tendrán una influencia poderosa en el pensamiento de finales de siglo, expusieron sin reparos la idea de que la mujer, en el proceso evolutivo de la especie humana, se mantenía en un estado equivalente al de la infancia.

No menos populares fueron los planteamientos del pionero de la frenología, el doctor Franz Joseph Gall (1758-1828), cuya teoría, según la cual, del estudio del cráneo se podía deducir científicamente la superioridad intelectual del hombre, fue criticada con argumentaciones de peso por Concepción Arenal (1820-1860) en La Mujer del porvenir. 1

La ciencia y la filosofía se unían para ofrecer argumentos al primer fanático que quisiera desarrollar su propia teoría pseudocientífica sobre la naturaleza degenerativa de la mujer, y justificar así la necesidad de someterla por su bien y por el de toda la humanidad

1 SCALON, G.: La polémica feminista en la España contemporánea (1868-1974). Madrid, 1986, pág. 164. 
Todo ello explica por qué en torno a 1900 el desafío de los movimientos feministas era visto, desde destacados sectores de la sociedad europea y estadounidense, como un síntoma de degeneración de la civilización occidental, que debía ser eliminado por el bien del progreso de la humanidad, surgiendo argumentos que se esforzaban en justificar la sumisión femenina desde las más diversas disciplinas: biología, antropología, medicina, psicología, filosofía, etc. ${ }^{2}$

Todas estas teorías caen en terreno abonado en un momento en el que está en auge el desprecio al cuerpo y a las ataduras impuestas por la naturaleza, no sólo por el impulso que recibe esta actitud dentro los sectores sociales más instruidos y vanguardistas, a través, en buena parte, de la popularización del idealismo alemán, sino sobre todo a causa de una estricta moral represiva en el terreno sexual que se impone principalmente en el sector burgués, en un período especialmente reaccionario y puritano, ganando fácilmente adeptos la sublimación del mundo del espíritu, que conduce al desprecio por las exigencias del cuerpo y en consecuencia, de todo aquello que las despierta.

Las letras y las artes no permanecerán al margen de estas consideraciones, "las obras de pintores, poetas y críticos muestran reiteradamente cómo durante los últimos 30 años del siglo XIX, la misoginia, las maravillas de la ciencia y la teoría de la evolución se habían conjugado para constituir la santa trinidad de la masculinidad contra esa entidad en regresión denominada mujer"3. En el debate que se abre en la sociedad sobre el lugar que en ella debe ocupar la mujer, hasta los científicos, literatos, pensadores y artistas más liberales mostrarán su lado más reaccionario.

En la conformación de la mentalidad de los jóvenes intelectuales vanguardistas, de los que Oscar Wilde (1854-1900) y el pintor Félicien Rops ${ }^{4}$ (1833-1898) son dos fieles representantes, jugó un papel clave la difusión de estas tesis. Unidas a la idea del superhombre de Nietzsche, que se pone de moda en determinados círculos, configurarán el núcleo de la ideología misógina que pesará sobre varias generaciones de varones intelectuales europeos, deseosos de reafirmarse a sí mismos descargando sus frustraciones sobre la mujer.

Dos son modelos de mujer más socorridos para el arte y la literatura de moda que constituyen dos caras de la misma moneda: la femme fatal y la mujer frágil.

La mujer fatal es el mito erótico por excelencia, la devoradora de hombres, la

\footnotetext{
2 Sobre las teorías antifemeninas desarrolladas en la época nos remitimos a SCALON, G.: Op. Cit, en concreto al capítulo 4: "Fuentes de autoridad del antifeminismo", págs. 159-194; DIJKSTRA, B.: Ídolos de perversidad. La imagen de la mujer en la cultura de fin de siglo. Madrid, 1994, págs. 160-173; BORNAY, E.: Las hijas de Lilith. Madrid, 1995, págs. 84-89.

3 DIJKSTRA, B. Op. Cit. pág. 182.

4 Su tema preferido será el de la mujer como símbolo del vicio y del pecado, la poseída y la diabólica. Los hermanos Goncourt exaltaron su capacidad para mostrar "el aspecto cruel de la mujer contemporánea, su mirada inflexible, su malevolencia hacia el hombre". FUGAZZA, S.: Simbolismo, Milán, 1991.
} 

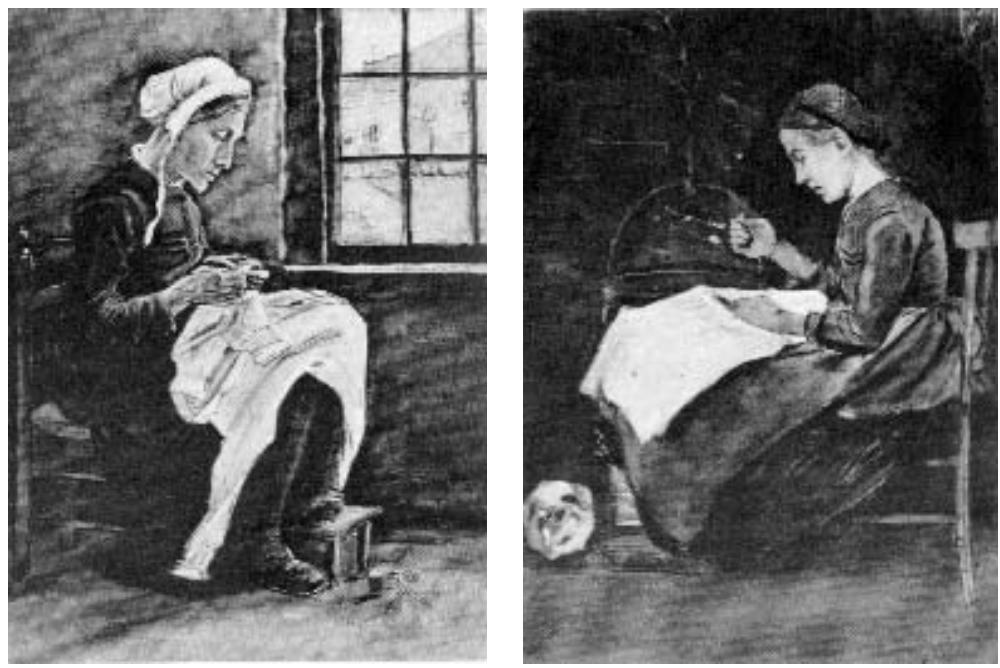

2. Mujer cosiendo (1881). Colección particular.

3. Mujer joven cosiendo (1881). Otterlo, Rijksmuseum Kröller-Müller.

encarnación de la tentación o la nueva Salomé que arrastra al hombre hacia la perdición, con un amplio numero de registros que van desde la aristócrata sofisticada hasta la joven obrera, la prostituta y la gitana.

El segundo prototipo, también con fuertes connotaciones eróticas, es la mujer frágil en la que toman cuerpo las fantasías erótico-místicas de los prerrafaelitas y que tendrá un gran éxito en toda Europa a partir de los años 1880. Así la veremos convertida en un ser etéreo y sublime, asumiendo tan pronto el papel de musa o de diosa, como el de santa idolatrada o mártir autosacrificada, de ángel virginal de inmaculada pureza y de eterna niña indefensa inspiradora de los más ardientes deseos.

Esta perversa atracción por la mujer frágil, fruto del rechazo por el nuevo modelo de mujer activa que exige un lugar en la sociedad fuera del dominio doméstico, se traducirá también en una morbosa atracción erótica por la mujer de salud y apariencia delicada: la enferma, la demente, la inválida y la moribunda, la perpetua convaleciente en un estado permanente de languidez, y por lo tanto, de pasividad absoluta. 


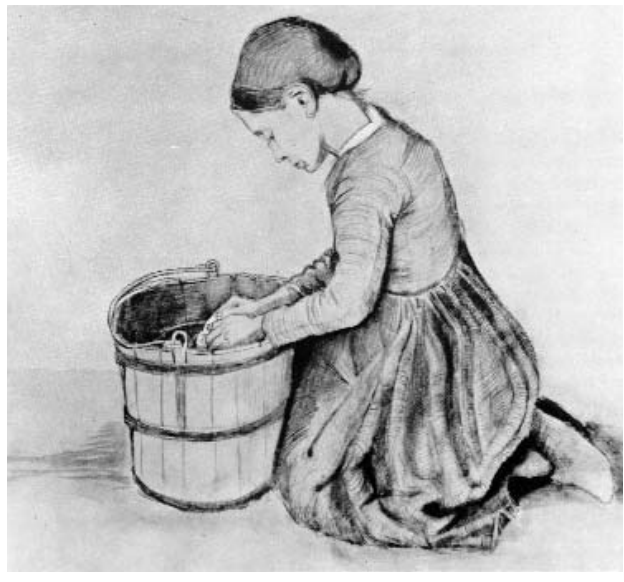

4. Niña arrodillada delante de un cubo (1881). Colección particular.

El ideal de feminidad de la época, al margen de la provocación erótica, sigue siendo el prototipo puritano que se ha dado en llamar el ángel del hogar. Ella es el pilar moral de la familia burguesa y representa a la humilde, asexuada, piadosa, sumisa, complaciente y entregada esposa dedicada exclusivamente a las labores domésticas y al cuidado de los hijos y el marido. Se trata de un modelo de mujer ya tradicional y ampliamente alabado en la pintura holandesa del siglo XVII.

Por su parte, el ámbito rural sirve de escenario para recrear dos prototipos femeninos a la medida de las aspiraciones del varón. Un modelo ya consagrado de la mujer como garante de las tradiciones y de la diversidad que se mantiene a salvo de la contaminación de ciertas modernidades, y al que acuden a inspirarse artistas y escritores. Además, en este ámbito, la mujer resulta ser más activa que el hombre en todas las tareas de interés antropológico que atraen a los pintores costumbristas: manufacturas y artesanía, faenas del campo, festejos, celebraciones religiosas, labores domésticas, sin olvidarnos del importante papel de la maternidad, la crianza y educación de los hijos a través de los que se perpetuará la tradición.

La mujer que, todavía en gran medida, para la mentalidad de la época simboliza la tradición en oposición al progreso representado por el varón, resulta más adecuada para ilustrar la esencia de las costumbres ancestrales del pueblo, y representar de forma emblemática la identidad cultural del territorio.

Esta "emblematizacion" de la mujer como garante de la tradición enlaza de nuevo con la Escuela holandesa del 600 que, de acuerdo con los valores cristianos, representó este ideal femenino como la virtud de la domesticidad desde una interpre- 
tación intimista, de la esposa dedicada al hogar, cristiana y discreta.

A la vez, el realismo más académico que pretende ofrecer una visión idílica y artificiosa del mundo rural elabora un prototipo de belleza de erotismo contenido. Se trata de una mujer joven, saludable, alegre e inocente que coquetea con el espectador.

Pintores contemporáneos que, al igual que Van Gogh, buscan el camino de la renovación artística como Cezanne, Gauguin, Degas, Matisse o incluso Manet, nos presentan una imagen de mujer que encaja perfectamente dentro de ese talante del varón intelectual finisecular que necesitaba considerarse como un ser superior a nivel moral e intelectual, una imagen que por otra parte se convirtió en síntoma de modernidad. Estos artistas presentan a la mujer como un ser eminentemente sexual y primitivo cuya naturaleza está próxima a la animalidad, o bien como seres indiferenciados, banales o estúpidos, sin carisma ni personalidad, con miradas vacías o expresiones unas veces vulgares y otras felinas.

El menosprecio de Manet se manifiesta en su falta de interés hacia el aspecto humano de las mujeres que representa. A diferencia de Toulouse-Lautrec que mostró una mayor sensibilidad y afecto hacia las mujeres de su entorno, se mantiene dentro de la "tradición antifemenina", que hace gala de una muy baja consideración hacia la dignidad de las mujeres, trasladándolas al lienzo como criaturas vacías, desprovistas de vida. De la misma manera que a Zola, la humanité de sus modelos les tenía sin cuidado ${ }^{5}$.

Esa falta de simpatía es especialmente manifiesta en Degas, quien llega a afirmar: "yo las presento sin coquetería, como animales que están aseándose"6.

Para Gauguin la mujer es la esencia de lo primitivo que se confunde con la naturaleza animal o vegetal, un ser puramente instintivo y sexual.

Por su parte, las bañistas de Cezanne transmiten una alegría intrascendente e infantil y responden al cliché cultural que se había impuesto en torno a 1900. Las representa sin rasgos físicos y psicológicos individuales, concebidas como reflejo unas de otras, dispuestas generalmente en círculos y fundiéndose en un todo con la naturaleza, del mismo modo que lo hacían los pintores más académicos en los cuadros de ninfas. Es la imagen de la mujer intrascendente, infantil y carente de identidad

Aunque Van Gogh no deja de ser permeable a los arquetipos femeninos de moda a los que hace referencia en una carta a Van Rappard en el que le habla de cual es el autentico camino a seguir en el arte:

\footnotetext{
5 HOFMANN, W. , Nana. Mito y realidad. Madrid, 1991, pág. 33.

6 Ibídem., pág.73.
} 


Q: artículos Covadonga López de Prado Mistral
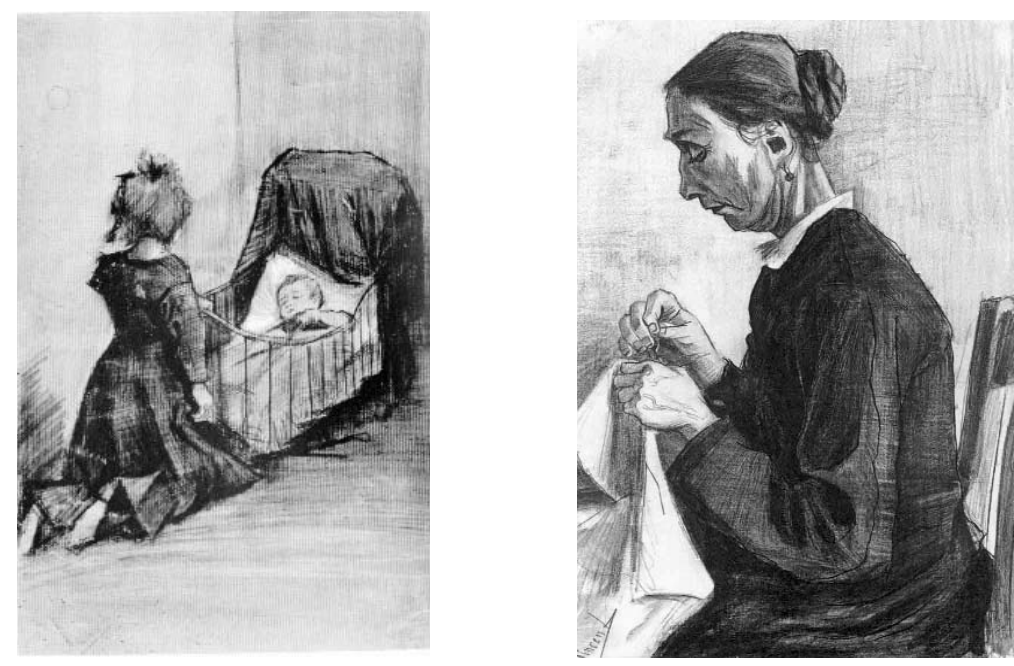

5. Niña arrodillada delante de la cuna (1883). Ámsterdam, Vincent van Gogh Foundation.

6. Sien cosiendo, media figura (La Haya, 1883). Rótterdam, Museum Boymans-van Beuningen.

"A mi manera de ver, hay dos tipos de "maîtresses". Al primer tipo pertenecen las que procuran amor, pero siendo conscientes (...) de que ese amor no es eterno, aquellas a las que uno no se entrega sin reservarse una puerta de salida (...).

Estas amantes excitan, adulan, miman y luego-luego-queman no pocos hombres.

Las "maîtresses" de la segunda categoría son diferentes. Encopetadas, fariseas, iijjesuitas!!!! Son las mujeres de mármol-heladas esfinges víbora- que quieren someter hombres (...). Estas amantes chupan la sangre, hielan a los hombres y los petrifican.

Lo que acabo de decirte es puramente artístico. Comparo el primer tipo de 'maîtresses', aquellas que queman, con la escuela artística que cae en la banalidad, y la otra, la categoría de las que hielan y petrifican, con la realidad académica (...)" (carta a Van Rappard, Etten, 12 de septiembre de 1881).

En su caso se trata sólo de un recurso metafórico. Frente a otros pintores, la imagen que transmite Van Gogh, que como ellos buscaba por encima de todo hacer 

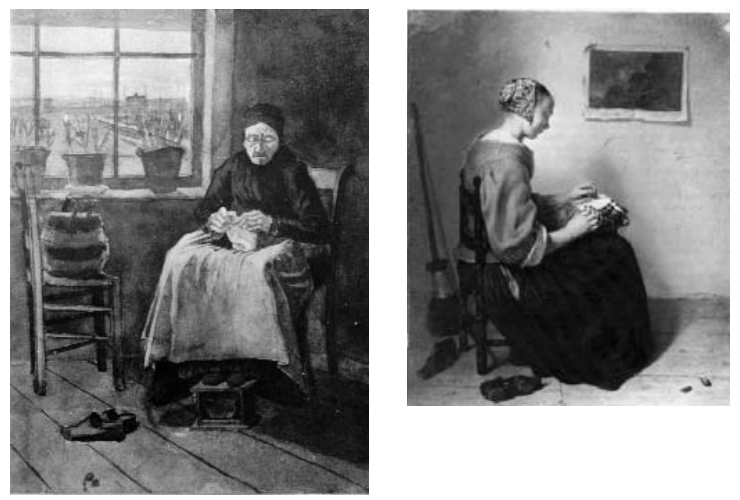

7. Mujer haciendo
punto junto a la venta-
na. (1882). En para-
dero desconocido.
8. Caspar Netscher,
Mujer haciendo boli-
llos, 1662. Londres,
Wallace Collection.

un arte moderno, parece mantenerse al margen del movimiento más virulentamente antifemenino y conserva una consideración hacia la mujer que encaja dentro del concepto tradicional del alma del hogar.

La dimensión erótica está ausente en sus imágenes femeninas, la mayoría de "sus mujeres", con la excepción de Sien - con ella introduce además de estas, otras variantes-, realizan tareas del hogar, cuidan a sus hijos o rezan, las campesinas también trabajan la tierra, las mujeres de clase acomodada, jóvenes o maduras, pasean, tocan el piano o leen, y siempre conservan una actitud modesta y recatada, como corresponde a la condición femenina de acuerdo con la moral tradicional burguesa. Pero por encima de todo, Van Gogh se sintió obsesionado por la idea de la maternidad.

\section{LA RELIGIÓN Y EL PRIMER FRACASO AMOROSO.}

Perteneciente a una familia burguesa, hijo y nieto de un pastor de Brabante, nuestro pintor había sido educado dentro de los preceptos del Partido de Groninga, movimiento reformista que surge en el siglo XIX dentro del calvinismo holandés. Los teólogos de Groninga, que aspiraban a hacer prevalecer una religión "sentida" frente a la frialdad del dogma, habían redescubierto La Imitación de Cristo de Thomas de Kempis. Esta reforma tenía un carácter esencialmente social, exigiendo la emulación de Cristo que se resumía en dos preceptos fundamentales para el buen cristiano: humildad y ayuda al prójimo. Fe, trabajo y fraternidad eran tres de los principios básicos de esta rama protestante, principios que harán mella en los planteamientos de Van Gogh. 

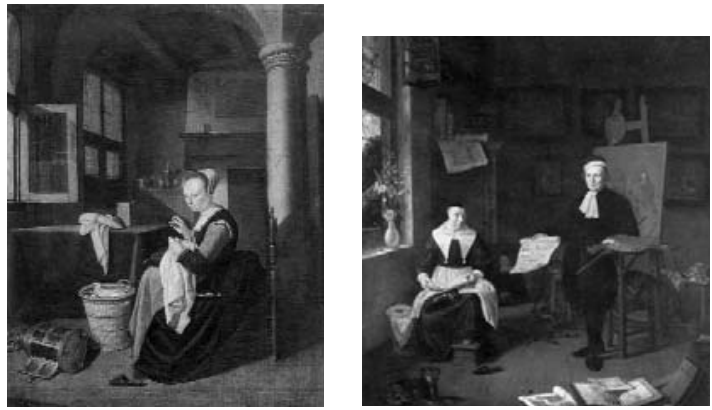

9. ADRIAEN VAN
GAESBEECK, Mujer
cosiendor Berlin,
Ge m äldegalerie,
Staatliche Museum
P re u s $i$ s c h e r
Kulturbesitz.
10. MICHIEL VAN
MussCHER, Retrato de
Michiel Comans II y su
esposa (1669). Ámster-
dam, Rijksmuseum.

La Escuela de Groninga recurrió sistemáticamente a las imágenes -entre las que se cuentan reproducciones de pinturas de maestros holandeses del pasadopara ilustrar sus textos religiosos y morales y divulgar así su doctrina. Un recurso que, como afirman Douglas W. Druick y Peter Kort Zegers, tenía un importante precedente en la literatura moral emblemática holandesa del siglo XVI y XVII. De hecho, esta nueva sensibilidad religiosa impulsó el renacimiento de esa forma de difundir los preceptos morales a través de imágenes sintéticas y del arte, hasta el punto de que a lo largo del siglo XIX fueron de nuevo publicadas las obras de los principales moralistas que en el siglo XVII habían recurrido a este sistema, entre los cuales destaca Jacob Cats. Su popular tratado titulado Houwelyck (1625) sobre el matrimonio y la vida en familia, ejerció ya en su momento una gran influencia en el arte holandés y era ahora actualizado, en lo que respecta a las ilustraciones, para continuar funcionando como una "segunda Biblia" con textos e imágenes investidos de un triple valor: amoroso, religioso y social.

Si bien en las cartas de Vincent no encontramos referencias explicitas a la obra de Cats o de Luyken, aquellas que escribió en su etapa holandesa "están llenas de expresiones coloquiales y metáforas que hunden sus raíces en esta tradición"7.

Tradicionalmente el Arte y la Religión habían definido las inclinaciones de los miembros de la familia Van Gogh en cuyo seno se habían venido desempeñando fundamentalmente dos profesiones: la de pastor y la de marchante de arte, aspectos que dejaran su impronta en la personalidad y convicciones del artista.

No menos importantes que la religión fueron sus experiencias y sobre todo sus fracasos amorosos, que son otro factor de peso a tener en cuenta a la hora de analizar su iconografía femenina.

Durante su estancia en Londres (13 junio-1873-15 mayo, 1875), como emple-

7Sobre este tema véase: DRUICK, D. W. y KORT ZEGERS, P.: Van Gogh e Gauguin. Lo Studio del Sud. Milano, Electa, 2002, págs. 11-12. 


\section{Sien con la niña en el regazo ( $L a$ H a y $a, 1883$ ). A ms terdam, Rijksmuseum Vincent van Gogh (Vincent van Gogh Stichting). 12. Sien amaman- tando al bebe (1882).}
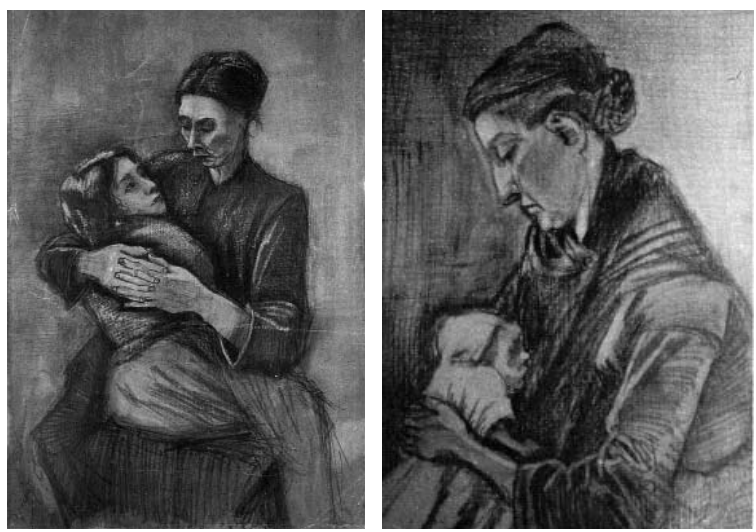

ado de la sucursal de la casa Goupil, Van Gogh sufre su primer desengaño amoroso al no ser correspondido por Eugenie Loyer, la hija de su casera, la cual, después de escuchar su declaración de amor le confiesa que está prometida en secreto.

La efusividad y fervor de este primer amor se verá sobredimensionado gracias a la lectura de L'Amour de Michelet (1858), obra que dejará una profunda huella en su concepto de la mujer y del amor.

En una carta a Theo escrita el 31 de julio de 1874 realiza el siguiente comentario que resulta ser muy elocuente por lo que respecta a cuales eran sus aspiraciones más intimas:

"Me pone contento que hayas leído a Michelet y que lo comprendas así. Un libro como ése al menos enseña a ver que hay muchas más cosas en el amor de lo que la gente acostumbra a buscar.

Para mi, este libro ha sido una revelación, y al mismo tiempo un evangelio. ¿No hay mujeres viejas?' no quiero decir que no haya mujeres de edad, sino que una mujer no envejece mientras ame y sea amada.

Y además, ique riqueza en un capítulo como 'Las aspiraciones del otoño'! Creo que la mujer es un ser totalmente diferente a un hombre (y un ser que todavía no conocemos, al menos que sólo conocemos superficialmente), como tú dices.

$Y$ también creo que un hombre y una mujer puedan formar uno, convertirse en uno, digamos formar un todo, y no dos mitades" (Carta 20)8. 
Sobre la influencia de la obra y pensamiento de Michelet volveremos más adelante, cuando a principios de los años 80 este autor recupere con fuerzas renovadas su ascendencia sobre Van Gogh, después de un periodo de retorno a la religión provocado por un nuevo desengaño amoroso.

Esta cita con la que Van Gogh parece identificarse plenamente, nos transmite, por un lado, un concepto de la mujer como un ser inaccesible para el hombre, de donde se deduce, por una parte, que la percibe como un ser complejo y misterioso, y por otra, que estamos ante un personaje con una fuerte dosis de romanticismo.

Por otro lado, Vincent concibe la unión del hombre y la mujer como un todo. Esto nos sitúa ante alguien que considera que la formación de una familia es la meta en la vida de todo hombre y toda mujer.

Pero sobre todo, este fragmento nos da pie para intentar hacernos una idea del concepto genérico que tiene sobre la mujer. $Y$ desde luego resulta evidente que no se alinea con las nuevas ideas antifemeninas que caracterizaron el periodo finisecular.

La necesidad de Van Gogh de compartir su vida, primero con una mujer para formar una familia convencional, y después de las frustradas experiencias amorosas, con una comunidad fraternal de artistas, es uno de los sentimientos más intensos y que más peso han tenido en su infructuosa búsqueda de la felicidad y en el desenlace final que lo llevo al suicidio. En definitiva, la soledad le resultaba insoportable y la idea de compartirlo todo le llevó a valorar a la mujer y a verla como esa compañera tan ansiada.

Los teólogos protestantes sostenían que el primer objetivo del matrimonio era aportar compañía, para lo cual citaban como fuente de autoridad el Génesis (2:18): "no es bueno que el hombre esté solo". Sobre todo insistían en que las mujeres debían de estar subordinadas y ser sumisas a sus maridos, no como esclavas, sino en calidad de socia leal en la empresa marital ${ }^{9}$.

El hecho de que hasta entonces la vida de Van Gogh se desarrollara al margen de las grandes urbes, donde la mujer de clase acomodada se había convertido en un ser inútil, un objeto de lujo para el varón, que exhibía como símbolo de su riqueza, y que con frecuencia en los círculos más frívolos se veía reducida a un ser eminentemente erótico, fue sin duda determinante. No debemos olvidar que en el ámbito rural y en los pequeños núcleos de población la mujer tradicionalmente había sido mucho más activa ya que, además de las tareas del hogar y la crianza de los hijos, compartía las labores del campo con el hombre, lo cual hacia que su consideración fuera más elevada.

\footnotetext{
8 La numeración de las cartas a Theo de Van Gohg se corresponde con la de la edición holandesa de 1952 y están tomadas de la traducción de Victor Goldstein publicada por Adriana Hidalgo editora, Buenos Aires, 2000, así como de la página web en la que esta traducida al inglés toda la correspondencia de Van Gogh.

9 FRANITS, W. E., Parangons of virtue. Women and Domesticity in Seventeeth-Century Dutch Art., New York, Cambribge University Press, 1993, págs.67-68.
} 
El rechazo de Eugene Loyer provocó un cambio radical en el ánimo de Vincent que cayó en un estado de melancolía y se volvió taciturno y huraño. En el periodo que va de 1875 a 1880 se refugia en la religión y pasa por una fase de fanatismo místico. Pretendiendo seguir el ejemplo de su padre, su modelo a imitar hasta entonces, decide convertirse en un pastor y sustituye sus preferencias literarias por la Biblia. Es entonces cuando llega a recomendarle a Theo que deje de leer a Michelet (carta 39). Será en la región minera de la Borinage, en Bélgica, donde desarrollará su apostolado como religioso seglar hasta que renazca su vocación artística.

\section{LA ETAPA DE ETTEN (ABRIL-DICIEMBRE 1881).}

En abril de 1881 después de una breve temporada en Bruselas, Van Gogh se establece en Etten en la casa de sus padres y allí, siguiendo las indicaciones de Mauve pintará a finales del año sus dos primeros cuadros.

Durante este periodo realiza numerosos dibujos, entre ellos los primeros sketches de El Sembrador y de Las Cuatro horas del Día de Millet. La razón por la que comienza a realizar estas copias, como explica en la primera carta que escribe a Theo desde Etten (carta 144), se debe a una metereología poco favorable. El tiempo no siempre era el adecuado para trabajar al aire libre y pintar paisajes, género que ocupará la mayor parte de su producción entre abril y septiembre.

A partir de septiembre, después de pasar unos días junto a Anton Mauve en La Haya ${ }^{10}$, su interés por la figura se acrecienta. Entonces se plantea la necesidad de perfeccionarse en el dibujo de la figura como parte de un programa para el futuro:

"Es preciso que dibuje sin descanso cavadores, sembradores, labradores, hombres y mujeres. Estudiar y dibujar todo lo que participa de la vida campesina" (carta a Theo 150).

Sin embargo, su repertorio de campesinos realizando faenas en el campo parece restringirse a los varones, ya que en esta época raramente recoge ese mismo tipo de actividad desempeñado por mujeres. Entre octubre y diciembre, cuando el tiempo empeora, se ejercita con dibujos de interior con personajes femeninos dedicados a las labores domésticas, pero insistiendo siempre sobre dos o tres moti-

\footnotetext{
10 Anton Mauve, casado con una prima de Van Gohg, es uno de los máximos representantes de la Escuela del Realismo Holandés y será una referencia fundamental para Vincent en su primera etapa artística. Él será quien le recomiende trabajar con modelos vivos, aspecto sobre el cual Van Gogh se mantendrá firme hasta el final frente a la postura de Gauguin.
} 
vos que repite constantemente como Mujer pelando patatas [1], Mujer cosiendo [2] o Mujer al lado de una ventana. Esta insistencia en un repertorio tan restringido, que también apreciamos en las labores del campo, se debe en buena parte a una cuestión de aprendizaje, pues en estos momentos la máxima aspiración de Van Gogh es la de ser ilustrador de revistas y su pretensión, según Evert Uiter, es contar con un stock de figuras en distintas actitudes que luego podría introducir en composiciones más grandes ${ }^{11}$. Por esta razón generaliza en la captación de los tipos que carecen de individualidad, donde la dimensión psíquica está minimizada, al contrario que en los estudios de cabezas de las campesinas y campesinos de Nuenen.

No estamos ante un conjunto de obras más o menos elaboradas, sino de ejercicios de figuras e interiores que, como ha observado Jan Hulskerde, fueron realizados de forma rápida por lo que presentan una calidad inferior a otras del mismo periodo. Así, mientras se aprecian evidentes irregularidades en la consecución de las proporciones de las figuras y de la perspectiva, a pesar del esfuerzo por alcanzar una relación armónica entre la figura y su entorno, parece que hay un empeño especial por trabajar la luz, que prácticamente en todos los casos define el perfil de las figuras y su entorno ${ }^{12}$. Pero además, este tratamiento lumínico les confiere a estas mujeres un áurea especial.

Estas imágenes femeninas, humildes, modestas y de una "rectitud intachable", que podríamos considerar como codificadas, y donde la incidencia de la luz es un factor plástico y conceptual importante, tienen mucho en común con la pintura de género holandesa del 600 , en donde nos encontramos una y otra vez con el mismo asunto: mujeres en interiores hogareños, absortas en sus tareas domésticas, cuya virtud más evidente es la modestia. La pose, la expresión, el atuendo y una estudiada iluminación se combinan para ofrecer una convincente construcción del ideal de feminidad y domesticidad. Son símbolos de la "virtud doméstica" de la tradición pictórica holandesa, reflejo de la mentalidad puritana de la clase media-alta ${ }^{13}$.

Por imágenes de "virtud doméstica" entiende Wayne E. Fraints, obras de arte que representan a la mujer en una relativa variedad de situaciones, muchas de las cuales la sitúan dentro del hogar y en relación con las obligaciones familiares. Su encanto y modestia ofrecen una visión del papel nuclear que la vida doméstica ocupa en la sociedad burguesa y son, por lo tanto, producto de un sistema de valores acerca de la mujer en una sociedad patriarcal14.

11 UITERT, E.: "Vincent Van Gogh, painter of peasants", Van Gogh in Brabant.'S Hertogenbosch (Noordbrabants Museum), 1987-88, pág.29.

12 HULSKER, J.: The New complete Van Gogh: paintings, drawings, sketches. Amsterdam: J.M. Meulenhoff, 1996, pág. 24

13 Sobre el tema de la virtud doméstica en la pintura holandesa del 600. Vid. FRANITS, W. E., Op. Cit.

14 FRANITS, W. E.: Op. Cit, pág. 1. 
La principal ocupación de la mujer entonces, y también en la época de Van Gogh, - al menos de la mujer perteneciente a la clase acomodada- era la maternidad y las labores del hogar, como coser e hilar y el cuidado de los niños.

Son diversos lo tratados que identifican la costura y otras labores domésticas con la virtud de la diligencia, idea que quedará bien reflejada en el arte. La labor de la costura era un motivo frecuente en la iconografía tanto de la joven casadera, como de la esposa y la viuda, y se relacionaba también dentro del lenguaje artístico, al igual que el hilado, con la virtud femenina de la domesticidad y la diligencia ${ }^{15}$. También encontramos muy a menudo en la iconografía femenina tradicional de la pintura costumbrista holandesa el tema de la mujer pelando patatas. Son tipos que se repiten de forma constante, frente a otros que apenas se representan o que simplemente, a pesar de formar parte de la rutina doméstica, como barrer o lavar la ropa, de los que existen escasos testimonios gráficos.

La exaltación holandesa de la domesticidad y la obsesión por la claridad, sobriedad, modestia y moderación hay que situarlo en el siguiente contexto: El "Hogar" existe en la mentalidad holandesa en calidad de polaridad dialéctica con el "Mundo", y en particular la calle, que trae el fango del mundo, literalmente, a su umbral. La lucha entre la mundanidad y el hogar es otra variación en la clásica contraposición holandesa entre materialismo y moral ${ }^{16}$. Este concepto del hogar como refugio lo encontramos también en Van Gogh, donde esta dualidad maniqueista se traslada también a la contraposición entre mundo rural y urbano como el equivalente a modernidad/tradición, falso/autentico

Volviendo a los dibujos que nos ocupan realizados en Etten durante los meses de octubre y noviembre, incluso hasta diciembre ${ }^{17}$, nos llama la atención el hecho de que los tipos dominantes son mujeres mayores, algunas ya ancianas. Se trata de una etapa del ciclo de vida de la mujer que recogió con profusión también la pintura holandesa, la cual mostró una clara veneración por la mujer anciana, generalmente en su condición de viuda. Las pinturas de este periodo holandés con ancianas y ancianos como protagonistas en temáticas diversas son sorprendentemente abundantes en relación con otros lugares de Europa. Las mujeres ancianas y viudas funcionaban como tópicos de los rasgos y virtudes estimables en las mujeres durante la etapa final de su vida. ${ }^{18}$

\footnotetext{
15 Ibídem, págs. 26-30.
}

16 SCHAMA: The Embarrassmente of Riches, una obra fundamental para el estudio del asunto doméstico en el arte holandés desde el punto de vista de un antropólogo social que recurre a las obras de arte como documentos. Citado por FRANITS, W. E. Op. Cit, pág. 3.

17 El primer apunte de este tipo -del cual realiza dos variantes con estudios de luz diversa-Mujer sentada cerca de la ventana, es del mes de septiembre. Por las mismas fechas dibuja tres apuntes de Hombre aventando el grano, dos de cavadores, cuatro de sembradores un Labrador apoyado en su azada y el mas conocido de Campesino sentado junto al fuego.

18 En relación con este tema véase FRANITS, W. E.: el capítulo “Weduve”en Op. Cit, pág. 161-194. 


Q: artículos Covadonga López de Prado Mistral

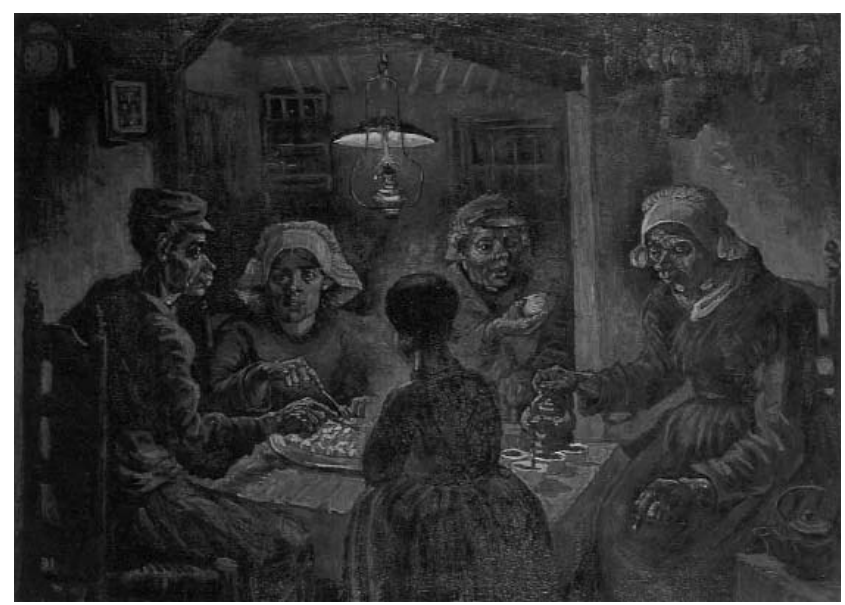

13. Los comedores de patatas (1885). Amsterdam, Rijksmuseum Vincent van Gogh, (Foundation Vincent van Gogh).

Seria lógico pensar que la elección de las modelos de esta serie de dibujos puede en parte estar condicionada por la dificultad de disponer de modelos jóvenes, de lo cual se queja en varias ocasiones, ya que resultaban menos accesible para un personaje como él, cuyo aspecto y carácter no debían de inspirar mucha confianza entre los campesinos de Etten.

Pero esta suposición no parece a primera vista muy sólida ya que, por un lado, tenemos una carta dirigida a Van Rappard en la que le dice que está realizando bastantes estudios a partir de modelos gracias a que ha encontrado algunos, tanto de mujeres como de hombres (Carta 1).

Por otro lado, una carta escrita a Theo desde Ámsterdam en enero de 1878, nos inclina a favor de la tesis de la selección intencionada de las modelos. En ella le expresaba a su hermano su preferencia, al menos como asunto artístico, por las mujeres feas y viejas, lo cual sin duda le aportaba mayor credibilidad a su obra en su empeño por alcanzar un realismo moderno. 19

19 Llega a Ámsterdam en mayo de 1877 para preparar su examen de admisión en el seminario de Teología, 


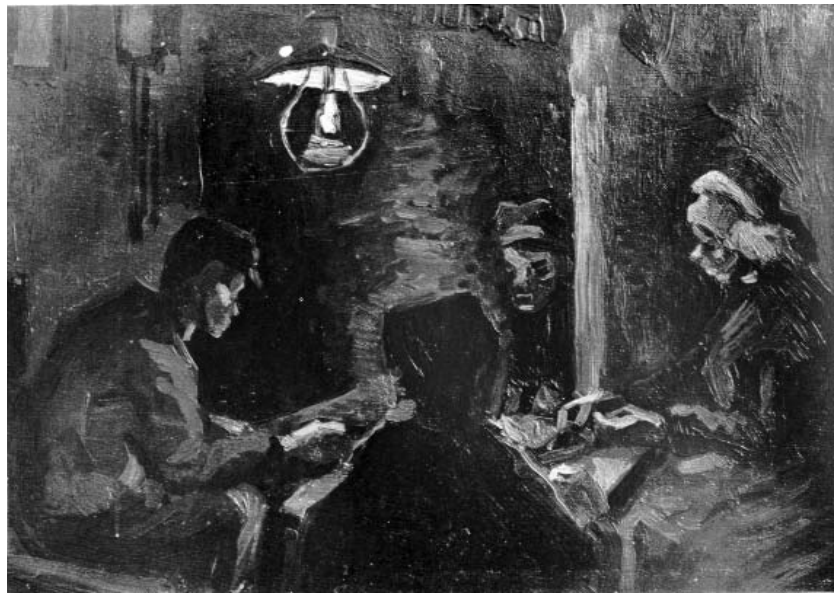

14. Cuatro figuras comiendo (1885). Amsterdam, Vincent van Gogh Foundation.

"C.M. (el tío Cornelius) me preguntó hoy si no me parecía hermosa la Friné de Gerome. Le dije que prefería de lejos una mujer fea de Israels o de Millet, o una vieja de Ed. Frere. Porque ¿Qué significa, hablando con propiedad, un bello cuerpo como el de este Friné?. También los animales tienen un cuerpo hermoso, y quizá más bello que el de los hombres; pero lo que los animales no tienen es un alma como la que se ve en los seres que Israels o Millet o Frere han pintado...

Ante esta imagen de Gerome, por lo que a mi respecta siento muy poca simpatía, porque no veo nada en ella, para mi no tiene sentido. Manos que muestran que han trabajado son más hermosas que las que se ven en ese cuadro. (...) M.C. me preguntó luego si no sentía nada por una mujer o por una muchacha que fuera linda; dije que tendría más sentimiento, que prefería vérmelas con una que fuera fea, o vieja, o pobre, o que fuera desdichada de una $\mathrm{u}$ otra manera, una a quien la experiencia de la vida o las penas hubieran dada razón y alma" (carta 117). 
A pesar de encontrarse en un ambiente rural, estas mujeres campesinas son representadas desarrollando labores dentro del hogar, siempre en actitudes recogidas, en silencio y centradas en su faena. Cualidades que definen a la perfecta esposa desde la época dorada de los moralistas holandeses del siglo XVII.

Contemporáneamente dibuja hombres jóvenes o de mediana edad sembrando, plantando o crivando y ancianos en el interior de la casa leyendo la Biblia o atizando el fuego.

Puesto que las mujeres de más edad se dedicaban a las tareas caseras que requerían menos esfuerzo: como coser, preparar la comida, etc podíamos pensar que no hay una selección intencionada por parte del artista, sino que responde a una realidad. Sin embargo, cuando, en menos ocasiones, dibuja mujeres jóvenes, la situación es la misma: Mujer cerca de la cuna y niña sentada en el suelo o Mujer joven cosiendo [3] y Mujer haciendo mantequilla.

Este repertorio doméstico incluye también a las niñas, en las que nos encontramos esa misma actitud humilde y aplicada: Niña arrodillada delante de un cubo [4] y Niña arrodillada, como la personificación de la promesa de la virtud doméstica.

Dibujadas ambas en el mes de noviembre, todavía en una carta que escribe a Theo inmediatamente antes de Navidad le comenta:

"En los días pasados he estado también dibujando niñas y he encontrado que me resulta muy grato" (carta 165 ).

De esta manera, vemos como Van Gogh recorre las tres fases de la vida de la mujer, tal y como era abordada por Jacob Cats en su famoso tratado Houwelyck (Matrimonio), ilustrado con emblemas sobre la vida en familia que incidían en las virtudes, labores y obligaciones de la hija, novia, esposa, madre y viuda, para definir un ideal femenino acorde con los principios morales burgueses que quedaría reflejado también en la pintura y grabados de la época. En él, Jacob Cats exhorta a la mujer a ser casta, diligente, silenciosa, obediente y a permanecer en el hogar desarrollando sus tareas domésticas para convertirse en una buena esposa.

Como ya dijimos más arriba, éste fue uno de los tratados más populares en la época dorada de la Republica Holandesa, cuyas ilustraciones de carácter emblemático sirvieron de fuente iconográfica a numerosos artistas cuya pintura de género hacia gala de un "realismo solo aparente porque no se limitaban a transcribir la vida cotidiana sino que transmiten ideales y asociaciones"20.

Debido al extremadamente limitado número de temas y a la repetición de formulaciones especificas, al realismo de Van Gogh podemos aplicarle también ese

20 FRANITS, W. E.: Op. Cit., pág. 6 
carácter de realismo selectivo construido de forma ficticia. El artista realiza una selección de la imaginería doméstica teniendo en cuenta las imágenes codificadas por la tradición y las convenciones sociales de un sistema de valores determinado, obviando otras tan reales como las por el representadas, como pueden ser escenas de mujeres trabajando en el campo, conversando, descansando, etc...

Según Evert van Uitert, sus "tipos de Brabante", tanto hombres como mujeres, forman parte del propósito de Van Gogh de realizar un arte real ligado con la vieja tradición pictórica (cartas 159-161) que era bien conocida en la Holanda de entonces gracias a los grabados que ilustraban los poemas de Jan Luyken, Het menselyk (Industria Humana) que fueron subtitulados como Vertoond in 100 verbeeldingen van ambachten, konsten, hanteeringen en bedryven (Despliegue en 100 representaciones de oficios, artes y actividades con versos) y publicados en 1694 . Ejemplos decimonónicos del mismo género son De Nederlanden. Karakterschetsen, kleederdragten, houtding en voorkomen van verschillende standen (Holanda, apuntes de caracteres, costumbres regionales, actitudes y apariencias de diversas clases) dibujados por Henry Bronw y publicados en 1841, y el exitoso álbum de 1861, De Kinderen der Zee (Niños del Mar) ilustrados por Jozef Israëls y con versos de Nicolaas Beets. Si bien estas obras habian perdido parte de su popularidad, se mantenían vigentes en muchas revistas ilustradas, y fue a través de ellas como influyeron en la definición de los tipos de Brabante de Van Gogh, que se remiten no solo en el arte holandés, sino también a los tipos ingleses. ${ }^{21}$

Pero sobre todo, no debemos olvidar el peso que tuvo la obra de Théophile Thoré (Williem Bürger), Le Musees de la Hollande, estudio sobre la pintura holandesa del 600. Esta obra figuraba entre los primeros textos formativos de Van Gogh que se entregó a su lectura durante su estancia en Londres junto con L'Amour de Michelet .

Thoré en su obra reivindicaba la "dignidad del realismo nórdico" así como la figura de Rembrandt y el simbolismo latente en su pintura, que enlazaba con la tradición emblemática, en contra de los prejuicios franceses que achacaban a esta escuela la carencia de carácter noble y de idealismo 22 .

Pero a diferencia de la pintura barroca holandesa de tema costumbrista, donde se rodea a la mujer con un sorprendente y limitado numero de objetos meticulosamente descritos, que forman parte de un lenguaje de convenciones, Van Gogh presenta a sus figuras en un entorno sobrio, definido únicamente por la luz, en donde la única prioridad es la de iluminar y situar correctamente a la figura en el

21 UITERT, E. van.: Op. Cit., pág. 29-30.

22 DRUICK, D. W.; KORT ZEGERS, P.: Op. Cit., pág. 16.

23 No se conserva ningún dibujo de modistas ejerciendo un oficio y si un número considerable de mujeres 
espacio. Estamos sin duda ante ejercicios de un principiante, con sus evidentes vacilaciones de carácter técnico.

Este repliegue hogareño que vemos en las escenas domésticas, reflejo de una mentalidad tradicional con respecto al hogar y el papel que en él desempeña la mujer, tienen a la vez una explicación práctica que nos facilita el propio Van Gogh en sus cartas.

La proximidad del invierno condicionó en primera instancia la elección del tema, y así se lo hace saber a Theo en una carta escrita el 3 de noviembre, la misma en la que le confía su amor por su prima Kee (carta a Theo 153). En ella dice que el frío le obliga a trabajar en interiores "dibujando figuras como modistas ${ }^{23}$, cesteros y otras semejantes". Puesto que la carta inmediatamente anterior data de mediados de octubre, Jan Huleker supone que el grueso de esta serie sería realizada en la segunda mitad de este mes y primeros de noviembre 24 . En diciembre, durante una estancia de varias semanas junto a Mauve en La Haya, insistirá sobre el mismo asunto y realiza pequeños sketches de una mujer cosiendo en la misma línea de las anteriores.

Es en estas fechas cuando dibuja a su hermana Willemina ${ }^{25}$ cosiendo a maquina, dibujo que no se conserva pero del que tenemos noticias a través de una carta (carta 146). Se trata de una imagen que considera no menos pintoresca que la tradicional de la mujer con la rueda de hilar, la cual se había convertido prácticamente en un icono de la virtud doméstica en la pintura holandesa de género.

Otro factor que sin duda estimuló esa fascinación por virtud doméstica fue el repentino y apasionado amor que le inspiró una mujer que encarnaba esas cualidades tópicas que esperaba encontrar en la mujer de su vida.

En el verano de 1881 Van Gogh se enamora de una manera casi enfermiza de su prima Kee Vos, viuda y madre de un niño de 4 años, hecho este que sin duda supuso un elemento de atracción importante para Van Gogh.

Convencido de que se trataba de la musa que necesitaba para desarrollar su arte y cumplir sus deseos de formar una familia, ignoró sus continuas negativas. Como respuesta a la violenta reacción de Vincent la joven viuda decide regresar a la casa de sus padres en Ámsterdam. Ante la tensión creada por la insistencia de Van Gogh, la familia - tíos, prima y padres- formó un frente común contra su tenaz voluntad de imponer sus sentimientos.

cosiendo como una tarea más del hogar.

24 HULEKER, J.: Op. Cit, pág. 24.

25 De las mujeres de su familia solo mantuvo relaciones continuadas con su hermana Willemina, destinataria de 20 cartas de la época tardía. A ella la represento en otras dos ocasiones, una a partir de una fotografía en 1881 durante su estancia en Etten y otra de memoria junto a su madre en Recuerdos del jardín de Etten en Arlés en 1888.El mismo año realiza el retrato de su madre. Van Gogh raras veces pintó a miembros de su familia, con la excepción de los citados y de un dibujo de su padre de 1881. 
Van Gogh, que no se resigna a aceptar un no por respuesta, se convence de que el rechazo de la joven es consecuencia de las presiones y beatería de su familia y así se lo comunica a Theo cuando el 3 de noviembre de 1881 lo pone al corriente de la situación:

"Quiero contarte algo que me pesa en el corazón (...).Estoy locamente enamorado de K.. Cuando me declare, ella me respondió que su pasado y su porvenir permanecerian siempre indivisibles para ella, y que por lo tanto nunca podría compartir mis sentimientos. Un terrible combate se libro entonces en mi corazón: ¿debía resignarme acaso a su "nunca, no, nunca", o, al contrario, negarme a considerar este asunto como terminado y conservar todavía un poco de esperanzas, no renunciar?.

Elegí la segunda solución. Hasta ahora no lamento mi decisión, aunque tropiece siempre con ese 'nunca, no, nunca'.

(...) Mientras tanto sigo trabajando, hasta mas fácilmente desde que la conocí.

(...) No me reproches que les falte al respeto a las personas más adultas que yo. De hecho, creo que ellas se oponen violentamente a este proyecto, y que tratarán por todos los medios de impedir que $\mathrm{K}$. $\mathrm{Y}$ yo nos veamos, hablemos o escribamos (...)

Estoy decidido a:

Amarla hasta que ella

Termine por amarme" (Carta 153).

Este empeño irracional, sobre el que insiste en las ocho cartas siguientes, le llevó al extremo de protagonizar el famoso incidente que tuvo lugar a principios de diciembre en la casa de Ámsterdam de su tío el pastor Stricker cuando irrumpió durante la cena exigiendo ver a su prima. Ante la negativa de los padres de ésta y de la propia Kee, colocó la mano sobre el fuego mientras suplicaba hasta perder el conocimiento:

"Dejadme verla solo por el tiempo que pueda mantener la mano sobre la llama", actitud extrema que dejo horrorizados a los presentes.

A través del amor que siente por Kee Vos, Vincent descubre el mundo de las mujeres, lo cual sin duda repercutiría en su trabajo, tal como se puede deducir a partir de afirmaciones como las siguientes:

"Desde que amo realmente, mi trabajo lleva más aún la marca de la realidad" (carta155). 


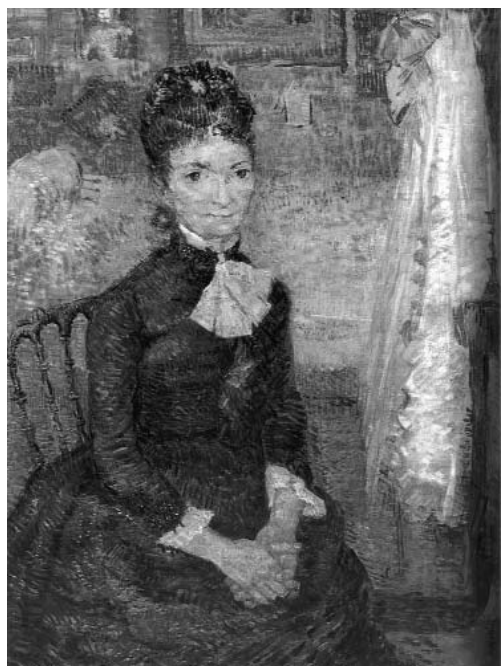

15. Mujer sentada junto a una cuna (París, 1887). Amsterdam, Rijksmuseum Vincent van Gogh,(Foundation Vincent van Gogh).

"Ese "Nunca, no, nunca" me enseñó al menos ciertas cosas que todavía ignoraba: $1^{\circ}$, me hizo comprender la inmensidad de mi ignorancia; $2^{\circ}$, me demostró la existencia de un mundo de mujeres [...]“ (carta 156).

Ese mundo de mujeres que con tanta ansia desea incorporar a su vida, puesto que para él representa el refugio del hogar, queda plasmada en toda la serie de dibujos de mujeres realizando tareas domésticas en un ambiente de recogimiento.

El nuevo revés amoroso y el rechazo que su comportamiento provocó en su entorno familiar derivó en un nuevo periodo de repliegue sobre si mismo, aunque esta vez no será precisamente en la religión donde busque refugio.

Como afirman Douglas W. Druick y Peter Kort Zegers: "Vincent interpretó este repudio como la prueba definitiva de que la religión practicada por su padre y su tío era esencialmente superficial y estaba dominada por rígidas convenciones farisaicas, en lugar de por la compasión sincera y por aquel amor por la humanidad que el encontraba en las obras de (Victor) Hugo y Michelet" 26.

Van Gogh asumirá las ideas de Michelet como una alternativa a las Sagradas Escrituras, sobre todo después de este segundo gran fracaso sentimental y del

26 DRUICK, D. W.; KORT ZEGERS, P. , Op. Cit., pág. 30 
escándalo familiar a que dio lugar su irracional e impetuoso comportamiento.

Jules Michelet, historiador y filósofo social, será el autor que más influirá en el pensamiento de Van Gogh durante los primeros años de la década de $1880^{27}$. Su ideología liberal burguesa quedará plasmada en su gran obra la Histoirie de la Révolution fançaise, que tendrá una fuerte ascendencia sobre las convicciones ideológicas del artista holandés. Michelet confiaba en que las distintas clases sociales podían convivir en un ambiente de cordialidad y amor mutuos. Este tipo de pensamientos de carácter social-cristiano encajaban perfectamente con el espíritu y la formación religiosa del pintor.

Su devoción por el historiador francés queda patente en una carta que escribe a Theo en Noviembre de 1881, en plena euforia amorosa:

"Pienso que obtendrás mas provecho leyendo a Michelet que la Biblia.

Por lo que a mi respecta, por nada del mundo podría prescindir de Michelet. Es cierto que la Biblia es eterna e imperecedera, pero Michelet ofrece consejos tan prácticos y claros que son directamente aplicables a esta acelerada y enfebrecida vida moderna en la cual tu y yo estamos inmersos, de manera que nos ayuda a mejorar (progresar rápidamente); no podemos prescindir de él." (carta 161).

El lugar que había ocupado hasta entonces su padre como modelo a imitar le corresponderá ahora a sus nuevos ídolos, hasta el punto de que a partir del otoño de 1881 comenzó a hablar de "El Padre Michelet" y "El Padre Millet". A raíz del ultimo enfrentamiento con su padre por negarse a acudir a la iglesia el día de Navidad, toma la decisión de abandonar Etten y salir hacia La Haya decidido a crearse una identidad independiente. Propósito éste que se materializa en la firma que adopta a partir de entonces reducida al nombre de pila "Vincent", obviando el apellido paterno.

Pero las obras de Michelet por las que mostró más interés y a las que se refiere en esta carta no pertenecían al género histórico, sino al de las relaciones domésticas, las obras en cuestión son dos tratados sobre amor y el matrimonio: L'Amour (1858) y La Femme (1859). En ellas el matrimonio y la familia eran considerados como la base de la estabilidad social, presentando a la buena y bien atendida esposa y el hogar como el último refugio de las incertezas e inseguridad de la vida moderna. Dirigidas a una audiencia masculina de clase media, Michelet preconiza la sacralidad de la vida conyugal y ofrece consejos sobre el adecuado cuidado y tutelaje que

27 Sobre este tema ver, SUND, J: True to temperamente. Van Gogh and French Naturalist Literature. New York, Cambridge University Press, 1992, págs. 41-45. 
el marido debe ejercer sobre la esposa para que el matrimonio tenga éxito.

El sentimentalismo de Michelet y su visión paternalista, y con frecuencia condescendiente, de la mujer como una encantadora criatura extraña cuya fragilidad exige una protección compasiva, tuvo un impacto imperecedero en el concepto de Van Gogh sobre la mujer. Todavía en una de sus últimas cartas a Theo (carta 617) incluye una cita memorizada de Michelet sobre la mujer 28.

Pero, como afirma Judy Sund, en 1881, después de su frustrada y no correspondida historia de amor, tenía una urgente necesidad de comprender la psicología femenina. La misma autora considera muy probable que esa preocupación por el amor y el matrimonio habría influido en el interés que muestra por las últimas novelas domésticas de Harriet Beecher Stowe o por Shirley y Jane Eyre de Charlotte Brontë con sus convincentes relatos sobre pasiones frustradas.

Beecher Stowe llama a la mujer a reconocer el carácter sagrado de su misión como esposa y madre, asociando la dignidad femenina y su realización como persona a la familia y al hogar. Es mas, asegura que a través del desempeño de las tareas domésticas se pueden expresar sentimientos religiosos.

Sobre la identificación de Van Gogh con estas ideas no cabe duda alguna:

"Michelet y Beecher Stowe... no te dicen que el Evangelio ya no tiene ninguna validez sino que muestran como se puede aplicar en nuestro tiempo, en nuestra vida, por ti y por mi, por ejemplo" (carta a Theo 161).

En la misma carta le recomienda a Theo leer las obras de Michelet, Beechr Stowe y Brönte y los sitúa a la cabeza de la moderna civilización junto con Carlyle y George Eliot que buscan lo real, lo eterno y la verdad y pone en boca de Michelet palabras como "limítate a una profesión y ama a una sola mujer".

Estas ideas, no sólo no contradicen, sino que vienen a confirmar la pervivencia y actualidad de aquellas que Van Gogh podía reconocer en la pintura de género holandesa del siglo XVII y en los principios en los cuales había sido educado. Vida, arte y literatura confluían componiendo un proyecto de vida global que llevará hasta sus últimas consecuencias.

La tradición pictórica (y moral) holandesa, el amor por su prima impulsado sin duda por su necesidad de refugiarse en un hogar propio, y la influencia de Michelet y la literatura inglesa condicionaron de forma inmediata las imágenes que Van Gogh nos dejó de la mujer como virtud doméstica en este periodo de su vida.

En resumen, estas imágenes de mujeres que tanto se aproximan a la de la llamada "virtud doméstica" son el producto de un concepto tradicional del papel de la

28/bídem., pág. 43. 
mujer en la sociedad, de lo observado, lo leído, la tradición pictórica en la que bebe el artista, sus propias necesidades existenciales o emotivas y de una climatología adversa que le impedía trabajar al aire libre.

Pero esta imagen permanecerá a lo largo de su vida y aflora constantemente en su obra posterior, tanto durante la etapa de convivencia con Sien, en Nuenem con Los comedores de patatas, como en su breve experiencia en la metrópoli parisina, adaptándola al modelo burgués y más urbano del "ángel del hogar", para culminar en Arlés con La Berceuse.

\section{La Haya. Sien (Diciembre, 1881-Septiembre, 1883).}

La referencia al modelo establecido en la pintura de género holandesa de la Edad de Oro parece esfumarse de repente en los trabajos que realiza en la Haya. $Y$ la explicación a esto, como no podía ser de otra manera, nos la ofrece de forma explicita en una de sus cartas.

En la misma carta (diciembre de 1881) en la que le cuenta a Theo el incidente que tuvo lugar en casa de sus tíos en Ámsterdam, después del cual pasó unos días en la Haya junto a Anton Mauve, Van Gogh reniega de la religión de sus padres y lanza un grito desesperado y a la vez esperanzado sobre la necesidad imperiosa de tener una mujer:

“(...) Ese muro de iglesia imaginario me valió un enfriamiento persistente de los huesos y la médula, sobre todo de los huesos y la médula de mi alma. Me repetí que no debía dejarme desorientar por ese sentimiento fatal. Pensé: quisiera tener una mujer a mi lado, no puedo vivir sin amor, sin una mujer. No daría dos centavos por la vida si no hubiera en ésta algo de infinito, profundo, real. Pero repliqué para mis adentros: Tú dices «ella y ninguna otra", y ahora irías con otra mujer, no sería razonable, eso peca contra la lógica. Ésta es mi respuesta a esa objeción ¿quién manda, la lógica o yo, la lógica me sirve a mí o yo sirvo a la lógica, acaso no hay razón e inteligencia en mi sinrazón y mi estupidez? Que actúe bien o mal, no puedo hacer otra cosa, ese maldito muro es demasiado frío, necesito una mujer, no puedo y no quiero vivir sin amor. No soy sino un hombre, y encima un hombre lleno de pasiones; necesito una mujer, de no ser así me congelaré, me petrificaré y me dejaré confundir. Tuve que entablar una lucha interior encarnizada, en cuyo transcurso se impusieron ciertas consideraciones relativa s a nuestro físico y a la higiene, que la amarga experiencia más o menos me ha enseñado. Uno no podría estar ni demasiado tiempo ni impunemente sin una mujer. No creo que aquello que algunos Ilaman Dios, otros el Ser Supremo, otros más la 
Naturaleza, sea irrazonable y despiadado. En pocas palabras, llegué a esta conclusión: voy a ver si no hay alguna manera de encontrar una mujer".

"Dios, no tuve que ir a buscarla muy lejos. Encontré una que estaba lejos de ser joven, lejos de ser linda, que no tenía ningún encanto particular, sí quieres. ¿Quizá tengas ganas de saber algo más? Era grande y sólidamente construida; no tenía manos de dama como K., sino de mujer que trabaja mucho. No era ni grosera, ni vulgar; había en ella algo muy femenino. Se parecía un poco a una figura de Chardin o de Frere, o hasta de Jan Steen. En pocas palabras, lo que los franceses llaman una obrera. Era visible que había tenido muchas preocupaciones, que la vida la había maltratado; joh! no tenía ninguna distinción, nada extraordinario, nada que no fuera banal. Cualquiera, a toda edad, si ama y si es buena, puede dar al hombre no el infinito del momento pero si el momento del infinito. Theo, le encuentro no sé qué de ajada que da tanto encanto al rostro de aquellas que han sido maltratadas por la vida. ¡Ah! ella tenía encanto para mi, le encontraba hasta alguna cosa de PeyenPerrin, de Perugin".

"Ten en cuenta que no soy tan inocente como un mocoso y que lo soy mucho menos que un bebé en su cuna. No era la primera vez que me abandonaba a esta veleidad de afecto, sí, de afecto y amor para este tipo de mujeres que los pastores maldicen, condenan y cubren de oprobio desde lo alto de su púlpito. Yo no las maldigo, no las condeno, no las desprecio. Tengo casi treinta años, ¿te das cuenta? ¿Realmente crees que nunca tuve necesidad de amor? (....) de ninguna manera puedo enterrar mi energía y mi vigor de espíritu a causa de ella (se refiere a Kee). El estimulante, la chispa que necesitamos, es el amor, y no precisamente el amor místico". (Carta 164)

Van Gogh no oculta que se trata de una necesidad que responde a unas exigencias sexuales más que sentimentales, exigencias que ve la posibilidad de satisfacer cuando en ese viaje conoce a Sien. Es por ello que en pocos días pasa con asombrosa facilidad del amor platónico y exaltado que sentía hacia su prima, una mujer que representa para el modelo de virtud doméstica, al consuelo que le aporta la compañía de una prostituta.

Sien, apodo de Clasina Hoornik de 32 años, es una costurera del suburbio de Geest que ejerce la prostitución para sobrevivir. En el momento de conocer a Van Gogh durante el viaje que realiza en diciembre a La Haya está esperando su cuarto hijo que nació cuando vivía con el29.

29 De estos cuatro hijos sólo superó la infancia Maria Wilhemina que tenía entonces 5 años. 
Durante su estancia en esta ciudad Sien será su modelo, amante y compañera.

La convivencia no será fácil desde el principio e ira deteriorándose con el tiempo cuando las repetidas promesas de matrimonio parecen caer en el vacío y Sien, que no responde al modelo de mujer dócil perfilado en el prototipo burgués del ángel del hogar en que la quiere convertir Van Gogh, se resiste a adaptarse a las exigencias de la vida hogareña burguesa.

Durante estos dos años (del 31 de diciembre de 1881 a septiembre de 1883) que pasa en La Haya ${ }^{30}$ se producen cambios importantes en su forma de concebir la vida y el arte que quedan reflejados en los dibujos y acuarelas en los que pretende plasmar la miseria y la pobreza de los suburbios urbanos. La proyección todavía un tanto idílica de la realidad campesina que nos ofrece en su obra anterior, influida por su propia visión burguesa de la realidad y por la escuela del realismo holandés que encabezaba Mauve, es abandonada a favor del realismo social inglés que conoce bien sobre todo a través de las ilustraciones de revistas como Illustrated London News o Graphic. Pero también, en su forma de ver la vida y el arte va a influir el Naturalismo de Zola de cuya literatura comienza a empaparse a partir de 1882

Paralelamente, ha dejado de abordar el tema femenino formulado de acuerdo con la tradición pictórica holandesa, y el concepto de la mujer como virtud doméstica - que identificamos con su prima Kee (viuda y madre virtuosa)-se transforma ante el deseo de convertirse en el salvador de la mujer perdida-Sien (una prostituta embarazada y abandonada por el padre de la criatura)- .

"Ayuda a tu esposa a convertirse en un espíritu libre y moderno, libérala de los prejuicios detestables que la aprisionan" (Carta a Theo, 160).

Este planteamiento no hay que interpretarlo como una toma de conciencia de la liberación de la mujer, sino del deseo de desprenderse de los prejuicios morales a los que culpa de su fracaso amoroso.

La fantasía masculina de rescatar a una mujer descarriada encaja perfectamente en la personalidad de Van Gogh. Imbuido de ideas mesiánicas y redentoras propiciadas tanto por sus lecturas como por su formación religiosa, se había convencido a si mismo de que tenia una misión que cumplir y esta la llevaría a cabo tanto desde el arte como desde vida, convirtiendo ambas una y otra en una misma cosa, con un objetivo común a alcanzar que daba sentido a su existencia.

De esta forma autojustificaba su "historia de amor" con Sien, otorgándole un

\footnotetext{
30 La presencia de Mauve, la posibilidad de convivir con una mujer y la situación insostenible a la que había llegado con sus padres, le llevaron a tomar la decisión de trasladarse a La Haya.
} 
fin noble a una cuestión puramente sexual y práctica derivada de la necesidad de disponer de compañía femenina y de modelos asequibles.

La principal razón que le lleva a tomar la decisión de vivir con Sien queda claro en una carta que escribe a Theo en diciembre de 1881, inmediatamente después de conocerla durante una breve estancia en La Haya. Precisamente en la misma carta en la que le cuenta su reciente, desesperada y ultima tentativa de conseguir a Kee:

"Quisiera tener una mujer a mi lado, no puedo vivir sin amor, sin mujer. No dará dos centavos por la vida si no hubiera en esta algo de infinito, profundo, real. Pero repliqué para mis adentros: Tu dices "ella y ninguna otra", y ahora irías con otra mujer, no sería razonable, eso peca contra la lógica. Ésta es mi respuesta a esa objeción ¿quién manda, la lógica o yo... No soy sino un hombre, y encima un hombre lleno de pasiones; necesito una mujer, de no ser así me congelaré, me petrificaré y me dejaré confundir. Tuve que entablar una lucha interior encarnizada, en cuyo transcurso se impusieron ciertas consideraciones relativas a nuestro físico y a la higiene, que la amarga experiencia más o menos me ha enseñado. Uno no podría estar ni demasiado tiempo ni impunemente sin una mujer. No creo que aquello que algunos llaman Dios, otros Ser Supremo, otros Naturaleza, sea irrazonable y despiadado. En pocas palabras, llegué a esta conclusión: voy a ver si no hay alguna manera de encontrar una mujer.

Dios, no tuve que ir a buscarla muy lejos. Encontré una que estaba lejos de ser joven, lejos de ser linda, que no tenía ningún encanto particular....

(...) El estimulante, la chispa que necesitamos, es el amor, y no precisamente el amor místico...." (carta 164).

Además de proporcionarle compañía y unas relaciones hogareñas, Sien y su familia le suponen, como decíamos, disponer de modelos baratos y adecuados al talante que quiere imprimir en su obra de acuerdo con el modelo inglés.

En varias ocasiones alude a ello. Así en una carta escrita a Theo el 3 de marzo de 1882 dice:

"Tengo un modelo nuevo, del que ya había tenido ocasión de hacer un estudio para un croquis superficial. O más bien, tengo varios, tres personas de esta familia posan para mi: una mujer de cerca de cuarenta y cinco años, exactamente una figura de Ed. Frére; su hija que tiene treinta años; y una niña, mas joven, de diez a doce años

(...) ahora vislumbro un poco la luz. Es agradable dibujar un ser humano, una cosa que vive; es endemoniadamente difícil, pero exquisito" (Carta 178). 
En otra carta a van Rappard se refiere a su condición social como el componente que precisa para su obra:

"Yo encuentro en ella justo lo que busco: su vida ha sido miserable y triste y la adversidad ha dejado en ella marcas, ahora yo puedo hacer algo con ella" (Carta 8).

Afirmación esta que adquiere su verdadera dimensión, una dimensión de intereses artísticos o creativos mas que sentimentales cuando leemos el siguiente comentario:

"Siento que mi obra se arraiga en el corazón del pueblo y que debo perderme en las clases más humildes para captar la vida en lo vivo y hacer progresos, aun al precio de muchas preocupaciones y esfuerzos" (carta a Theo del 11 de mayo de 1882 - carta 197).

A la vez, Sien supone la última oportunidad para realizar el ansiado proyecto de formar un hogar, tal como se deduce de estas palabras en las que también se vislumbran sus intereses artísticos:

"Yo quiero ir a través de las alegrías y las penas de la vida en familia para pintarla desde mi propia experiencia" (carta a Theo, mayo, 1882).

Está claro que para Van Gogh la vida y el arte transcurren por el mismo camino y las motivaciones sentimentales parecen estar al servicio de su realización como artista.

"Creo que cuando más se ama, más actividad se despliega, puesto que siempre me negaré a considerar como amor, un amor que sólo fuese sentimiento... "(carta a van Rappard entre marzo y mayo de 188331).

Aunque tampoco podemos minimizar lo que la vida doméstica significaba para él. Este sentimiento parece intensificarse en el momento en que nace el niño, que según sus palabras es como un rayo de sol en su vida. La cuna representa para él toda la ternura y el calor del hogar y le inspira los dibujos más entrañables, ajenos a la tristeza que emana de los demás, como un apunte del niño en la cuna al lado

31 Las referencias a las cartas dirigidas a Van Rappard están tomadas de: Vincent Van Gogh, Cartas a Van Rappard. Traducción del francés de Gabriel Ormaechea. Barcelona: Parsifal Ediciones, 1992. 
de la estufa (carta a Theo 218) o el de Niña arrodillada delante de la cuna [5], incluido también en una carta a su hermano (carta a Theo 276 , de marzo de 1883)

Si bien lo que la cuna, el gesto de mecer la cuna o de añorar su balanceo significa para él lo trataremos más adelante al referirnos a, La Berceusse - que fue su gran y personal creación en lo que respecta a la iconografía de la virtud doméstica y la maternidad-, no podemos resistirnos a reproducir un párrafo de la carta en la que describe su nuevo estudio:

“... cerca de la ventana que da al astillero y la pradera que conoces por el dibujo, un gran sillón de mimbre para Christine (Clasine), y al lado una cuna de hierro recubierta con una manta verde. No puedo mirar esa cuna sin sentirme emocionado, ya que el hombre se siente invadido por una sensación profunda y poderosa cuando está sentado al lado de la mujer que ama, cerca de una cuna donde descansa un niño" (Carta a Theo 213).

Si bien el carácter de los dibujos que realiza en esta etapa cambia sustancialmente con respecto a la anterior, Van Gogh sigue mostrando un interés especial por las imágenes de la vida doméstica como ámbito "natural" de la mujer y en las que recoge ahora su experiencia personal con Sien y la familia de esta. Según Carol Zemel en la Haya realizó aproximadamente 69 dibujos y acuarelas de mujeres y la vida doméstica tomando como modelo a Sien, así como otros miembros de su familia, al menos a partir del mes de febrero ${ }^{32}$ : su madre, una hermana de 12 años, su hija de 5 y el hijo que nace en junio cuando Van Gogh está internado en el Hospital a causa de una enfermedad venerea.

No nos vamos a detener demasiado en el estudio de las imágenes de Sien, ya que de ellas Carol Zemel ha realizado un estudio en profundidad, el mismo en el cual basamos nuestras propias reflexiones. Nos interesa sobre todo constatar la pervivencia de la idea de virtud doméstica como ideal de feminidad en Van Gogh.

Aunque su referencia artística cambia, no renuncia al prototipo de mujer tradicional e insiste en las imágenes de Sien como madre y en el entorno hogareño como su espacio natural. Incluso la vemos encarnar a la emblemática Costurera (1883) que tantas veces dibujara en Etten siguiendo los modelos tradicionales [6]. Si bien es cierto que su ideal femenino ya no es la virtuosa mujer que veía en Kee, la diferencia es que ahora se propone reinventarla él mismo como si fuera un Pigmalion haciendo realidad su "fantasía victoriana favorita: la caridad, el perdón y la salvación del prójimo" 33 donde asume el rol del "salvador masculino" con conciencia social.

32 "Sorrowing Women, Rescuing Men: Van Gogh's Images Of Women And Family". Art History, vol. 10, n 3 , septiembre, 1987, pág. 351.

33 ZEMEL, C.: "Sorrowing women, rescuing men. Van Gogh's Images of Women and Family". Art History, 
A los primeros días de este periodo pertenecen varios dibujos que se mantienen en la línea de los realizados en Etten, pero nos interesa detenernos especialmente en una variante del tema Mujer cerca de la ventana haciendo punto [7] realizada a mediados del mes de enero de 1882, y que se encuentra en paradero desconocido $^{34}$. Nuestro interés se debe a la presencia de los zuecos en el suelo junto a la mujer, ya que se trata de un motivo que aparece con cierta frecuencia en la pintura holandesa. En composiciones semejantes a la de Van Gogh lo podemos ver en pinturas de género holandesas del siglo XVII formando parte del entorno doméstico de imágenes de mujeres en el hogar, como en Mujer haciendo bolillos (1662) de Caspar Netscher [8], La carta de amor de Johannes Vermeer, Mujer que lee de Pieter Janssen Elinga, Costurera junto a una cuna de Gerard ter Borch, Mujer cosiendo de Adriaen van Gaesbeeck [9], o en la obra de Michiel van Musscher, Retrato de Michiel Comans II y su esposa (1669) [10]. En esta última, como en el dibujo de Van Gogh, nos encontramos con una anciana que está cosiendo sentada al lado de una ventana con los pies sobre un escabel, y delante de ella el zapato descalzo en el suelo.

Este motivo fue estudiado por Wayne E. Fraints, según el cual, los zapatos descalzos se asociaban, ya desde las Leyes de Plutarco con la permanencia de la mujer en la casa. El mismo autor afirma que en la emblemática y en los grabados holandeses los zapatos descalzos simbolizaban la virtud doméstica y servían por lo tanto también en la pintura como metáfora de la domesticidad. De esta manera explica él porqué de la presencia de zapatos próximos a personajes femeninos en la pintura holandesa de tema domestico del siglo XVII35.

Aunque no es un tema a tratar en este trabajo, con este simbolismo debería ponerse en relación el recurrente tema de los zapatos, como elemento aislado, en la obra de Van Gogh.

Obligado de nuevo por el mal tiempo a replegarse en el hogar, en abril abandona temporalmente los dibujos de exteriores y se centra en el de figuras. Por estas fechas realiza varios dibujos con Sien como modelo, con escenarios muy sobrios como: Figura de mujer sentada con la cara apoyada en la mano, como una metáfora existencial de la melancolía, Sien cosiendo, Mujer rezando, Sien con la niña en el regazo [11], Sien amamantando al bebe [12], Sien con cigarro sentada en el suelo. En todos ellos descubrimos ya un tratamiento de la figura y un enfoque moderno que abandona las referencias tradicionales. En estos dibujos, a excepción del último, "lo particular se convierte en general, lo individual en prototipo, y la condición de la vida

10 (1987) pág. 355.

34 HULSKER, J.: Op. Cit., fig. 90 (acuarela, $33 \times 26 \mathrm{~cm}$.)

35 FRANITS, W. E.: Op.Cit., págs. 77-79. 
de Sien adquiere estatus y significado universal". Ella encarna los roles femeninos de ama de casa, madre y mujer piadosa. Sin embargo no son imágenes emblemáticas del hogar feliz sino que proyectan una sensación de tedio y tristeza. ${ }^{36}$

Sin lugar a dudas, el dibujo más representativo de esta época que transcurre en La Haya y que marca el inicio de una nueva etapa artística es el de Sorrow -Tristeza- (Abril, 1882) del que realiza tres versiones de las cuales solo se conservan dos y una litografia [13]. Este es el primer dibujo que envía a Theo desde La Haya del cual le había adelantado varios apuntes en una carta (carta 186). Se trata de un desnudo de Sien completamente deserotizado por el embarazo, rodeado de una vegetación mas simbólica que de ambientación, que inspira desolación y dolor. Con el se sitúa en el polo opuesto de la iconografía de genero.

En éste como en tantos otros dibujos Sien se convierte en un prototipo de género, y como afirma Carol Zemel, esta obra representa el estatus de la mujer caída. Pero también, está representando "los problemas, no los placeres, que conlleva la sexualidad femenina". Van Gogh nos sitúa ante la mujer como un rehén de la Naturaleza, un concepto muy extendido en la época donde la mujer y su sexualidad eran contempladas con "mirada de zoólogo".

Sin embargo, en su obra está ausente el carácter sórdido y distante con que los pintores y literatos de estos años describen a la prostituta. $Y$ es que el pintor holandés, con su mentalidad evangélica, está más predispuesto a asimilar las teorizas de ciertos moralistas victorianos que entienden que la causa de la prostitución se encuentra en la sociedad y no en la naturaleza promiscua y delincuente de la mujer, tal y como defendían personajes como Lombroso y Ferrero. Su teoría pseudocientífica tuvo un enorme éxito a todos los niveles a raíz de la publicación en Italia en 1893 del libro titulado La donna delinquente, la prostituta e la donna normale, con el cual contribuirían a afianzar la creencia, ya muy extendida, de que la prostitución no era más que la afloración de la tendencia criminal latente en la mujer.

Las ideas paternalistas que Michelet expone en La Femme (1860) siguen intactas en la mente de Van Gogh como lo confirma el hecho de que el dibujo que envía a Theo contenga una cita manuscrita tomada del historiador y filosofo francés: "Como puede una mujer estar sola, abandonada sobre la tierra" que transmite la noción de mujer como victima, no como pecadora y deja traslucir su fantasía de rescate. Representa a Sien como una mujer abandonada por la sociedad, no como una puta. Nos sitúa ante un crimen social, no ante un "crimen sexual".

Carol Zemel analiza la influencia que La Femme de Michelet ejerció en estos momentos sobre Van Gogh. Esta obra trata los peligros de la sexualidad que amenazan a la mujer soltera de clase obrera. Pero, afirma la autora, lo que lo distingue

36 ZEMEL, C.:, Op. Cit., pág. 360 . 
de sus contemporáneos es la creencia de que la mujer caída puede ser regenerada por el amor. La familia es el refugio de la mujer caída y dentro de ella, como dice Linda Nochlin, se convierte en el "ángel del hogar". En el capitulo titulado No hay vida para la mujer sin el hombre afirma que la naturaleza ha establecido un lazo entre el hombre, la mujer y los hijos y solo juntos pueden salvarse. Esta doctrina cristiana del amor como redentor cuajó sin duda en el temperamento evangélico y utópico de Van Gogh. El hogar se constituye como un lugar perfecto para las relaciones amorosas, y es la única esperanza para el orden social burgués. Solo dentro de una familia, protegida por su marido, la mujer puede cumplir su cometido: criar a sus hijos y crear un entorno productivo y espiritual a la vez, de amor y confort 37 .

En las cartas a Van Rappard deja claro tres ideas ya apuntadas: su fantasía de rescate, la convicción de que la salvación de Sien pasa por la vida en familia y la sublimación de su papel como madre, y la idea de la prostituta como victima de una condición social desfavorable.

En una carta sin fecha pero escrita en 1883 en la que agradece a su amigo la comprensión que ha mostrado después de confesarle su historia de amor con Sien, están implícitos estos tres aspectos:

“(...) Se trata de una mujer que, en el momento que la encontré, parecía tener un pie en la tumba, y cuya inteligencia y sistema nervioso estaban quebrantados y desorientados. Según un profesor de Leyde su única oportunidad de salvación era la tranquila vida en familia.... por lo que a su vida concierne, creo que tú no condenas más que yo a las mujeres que han caído. Frank Hol ha expresado eso en un dibujo... A este dibujo le puso la siguiente leyenda: No es su voluntad la que consiente, sino su pobreza.

(...) los que abandonan a una mujer embarazada no saben lo que hacen-es un niño muy agradable, un rayo de cielo que ha descendido en mi casa. Por lo que respecta a la mujer, ¿te acuerdas de la frase de Gavarni: si hay una criatura insoportablemente estúpida y mala, es la jovencita- si hay una criatura sublime y abnegada, es esa misma jovencita convertida en madre (...) la pizca de vanidad que hay en la mujer antes de ser madre, es reemplazada más tarde, cuando debe sacrificarse por sus hijos, por algo sublime". 38

Si la referencia literaria era Michelet, la artística se encontraba en las revistas inglesas como Illustrated London News y Graphic donde "el núcleo familiar era representado como modelo ideal de vida" con un tono melodramático y marcada-

37 ZEMEL, C.: Op. Cit., pág. 359.

38 VAN GOGH, V.:Cartas a Van Rappard, Op. Cit, págs. 99-101. 
mente sentimental y pintoresco. Aspectos estos últimos de los que rehuye Van Gogh

Al poner el énfasis en la línea, sobre la cual recae toda la fuerza expresiva de la figura, Van Gogh moderniza su estilo, de manera que los recursos plásticos, más concretamente, el lenguaje gráfico, se convierte en el verdadero protagonista frente al tratamiento descriptivo y anecdótico del arte victoriano.

Sien representó para él la intimidad hogareña, pero también la tristeza y melancolía o quizás el misterio y complejidad del género femenino. A ello responden los numerosos dibujos en los que toma a Sien como modelo de un tipo o un estado de ánimo más que como una individualidad concreta y que son la viva imagen de la desesperación. A esta serie temática pertenecen distintas variantes del tema: Mujer sentada en una cesta con la cara entre las manos (Marzo, 1883).

En ellos también se pone de manifiesto el deterioro que sufre la relación en los últimos meses de convivencia, cuando de nuevo ve frustrado su proyecto de crear un hogar, al tropezar con el carácter indomable de una mujer que por su origen social tiene un talante que no encaja dentro del patrón burgués de Van Gogh y que se niega a ser "salvada" y "domésticada".

En estos meses, cuando Sien vuelve a prostituirse y se siente contrariado ante la resistencia de ella a ser reformada y no poder llevar a cabo su fantasía de rescate y del hogar feliz, su opinión sobre la causa de la prostitución parece cambiar radicalmente. Citando de nuevo a Michelet afirma que la mujer es una enferma y un ser variable, y, en consonancia con la difusión de las teorías evolucionistas antifemeninas, afirma que el retroceso es consustancial a la naturaleza femenina ${ }^{39}$. Afirmaciones en las que ya se adivina la influencia de Zola, y que se hace patente en el siguiente fragmento de una carta a Theo:

"Se que hay diferencias, pero también semejanzas entre mi actitud hacia ella y el pasaje de L'Assommoir (de Zola) donde el herrero ve como Gervaise se equivoca pero no tiene la más mínima influencia sobre ella; a causa de su hipocresía y su incapacidad para ver las cosas claras, ella no puede comprender cual es el camino que debe tomar.

La compadezco más que nunca porque veo que está más angustiada que nunca. Pienso que, por el momento, no tiene mejor amigo que yo, un amigo que podría ayudarla con todo su corazón si me lo permitiera... me temo que ella no es capaz de comprender que está actuando de forma errónea, o no quiere verlo..." (carta 317).

39 ZEMEL, C.: Op. Cit., pág. 364. 
A manera de conclusión podemos decir que en la obra de este periodo Van Gogh reincide en su ideal de la virtud doméstica, encarnado en la figura de Sien, pero ahora no se trata de acudir a imágenes convencionales inspiradas en un modelo de virtud tradicional. Estas nuevas imágenes domésticas forman parte de un proyecto de redención moral y de una fantasía en la que se ve a si mismo como el salvador y protector de una mujer que debe ser rescatada a toda costa, sin tenerla en cuenta como sujeto. $\mathrm{Y}$ el rescate consiste en restituirla al destino que la naturaleza le ha reservado a la mujer y que solo el hombre puede proporcionarle: el de ejercer como esposa y madre.

El modelo artístico a seguir ya no es el que le proporcionaban las escenas de genero de la Edad de Oro de la pintura holandesa, sino el arte gráfico popular inglés de temática social del que suprime el carácter melodramático $\mathrm{y}$, como ya había hecho con sus modelos precedentes, la acumulación de detalles.

\section{LAS CAMPEsinAs de Nuenen (DICIEMBRE 1883-NOVIEMBRE 1885).}

Durante su estancia en Nuenen los valores que le había transmitido la pintura de Millet están más presentes que nunca. Van Gogh se centra en la representación del campesino y desde su posición de observador burgués nos ofrece una visión primitiva y elemental, que responde a su afán por realizar un arte moderno. Para ello, recurre a la fealdad con el objeto de ofrecer una visión más autentica, en contraposición al realismo edulclorado y melodramático del costumbrismo que triunfa en los salones y en la ilustración grafica, de escenas rurales pobladas de bellas y saludables jóvenes puras e inocentes.

Van Gogh escruta de forma insistente y casi obsesiva los rostros de las mujeres y a través de una multitud des estudios de cabezas nos transmite el alma y la tristeza de estas campesinas.

Pero si bien la imagen de la virtud doméstica parece quedar al margen de esta etapa, debemos tener en cuenta que todos sus trabajos en Nuenen forman parte de un proyecto más ambicioso, una pintura de composición para exponer en el salón que se concreta finalmente en Los comedores de patatas (1885) [13].

En las modificaciones que introduce a lo largo del proceso creativo queda patente, como ha puesto de manifiesto Giselda Pollock, hasta que punto sigue vivo su interés por la imagen de la mujer como alma del hogar. En los primeros apuntes la figura que sirve café ( Cornelia de Groot) no aparece [14]. Introducida con posterioridad, en el lienzo definitivo su presencia ha adquirido mayor protagonismo al separarla de la acción principal, darle mayor monumentalidad y espacio y enfatizando su presencia al rodearla de objetos de cocina descritos con detalle a la vez que el hombre que se encuentra a su derecha se vuelve hacia ella. Se convierte así en 
figura clave de la dinámica del grupo, en la madre, en el elemento esencial de la familia. 40

\section{LA Berceuse (ARLÉs, 1888-1889).}

Una vez agotado el filón que le proporcionaba el mundo rural como fuente de inspiración para configurar un arte propio y como forma de vida, la virtud doméstica sigue estando presente en su iconografía desde su breve estancia en París hasta el final de sus días. Pero ahora la encontramos encarnada en el prototipo de mujer burguesa: mujeres tocando el piano, leyendo o velando el sueño de su hijo, como en Mujer sentada junto a una cuna (París, 1887) [15]. Una imagen está ultima que podríamos considerar como un precedente de La Berceuse (Arlés, 1888-1889), visión sintética y renovadora con la que culmina su proyecto artístico y que parece recoger sus más intimas aspiraciones.

"A la larga el hombre no puede vivir en alta mar: necesita una cabaña en el litoral, un fuego en el hogar, una mujer e hijos en torno a ese hogar". (Carta a Van Rappard, 23 de noviembre de 1881). ${ }^{41}$

La idea de la mujer como madre que para él representa el refugio del varón, queda sintetizada en ese icono que resume su idea de la virtud doméstica. Lo que separa aquellos dibujos realizados en Etten influido por las imágenes codificadas de la pintura tradicional de genero holandesa, con sencillas y modestas mujeres sentadas al lado de la ventana realizando las tareas del hogar, hasta los cinco lienzos de La Berceuse concebidos como un emblema, un icono moderno, pasando por los dibujos de Sien y su hija, solo hay una cuestión de madurez artística y son el resultado de una atormentada búsqueda en la que arte y vida se funden.

La palabra francesa "berceuse" significa en primera instancia "mujer que duerme a los niños" y de esta se deriva la segunda acepción como "nana" o "canción de cuna". Un significado que entraña un profundo sentimiento para Van Gogh tal como pudimos comprobar a través de los dibujos que realiza durante su etapa de convivencia con Sien.

En la carta a Theo del 28 de enero de 1889 en la que le habla de esta tela donde retrata a Augustine Roulin 42 recurre de nuevo a la imagen del hombre en alta

40 POLLOCK, G.: "Van Gogh an the poor slaves: images of rural labour as modern art", Art History, Vol. II, $\mathrm{n}^{\circ} 3$ (1988), pág. 419.

41 En el hospital de Saint-Rémy en 1889 pinta un óleo en el que vemos como este anhelo se mantiene entonces más vivo que nunca. Se trata de una versión que realiza de la obra de Virginie Demont-Breton, El padre está en alta mar, en la que representa una mujer con su hijo en el regazo que espera adormecida al lado del fuego del hogar el regreso del marido que está en alta mar. También en Saint-Rémy realiza Anochecer y Primeros pasos según Millet en las que insiste sobre esas visiones hogareñas del grupo familiar. 
mar, en este caso para asociar el vaivén del barco con el mecimiento de la cuna, que nos sitúa otra vez ante ese fuerte sentimiento de añoranza por la figura materna.

"Creo haberte dicho ya que además tengo una tela de 'Canción de cuna', justamente aquella en la que trabajaba antes de que mi enfermedad la interrumpiera. También de ésta hoy poseo dos versiones.

Sobre esta tela acabo de decirle a Gauguin que, como él y yo hablamos de los pescadores de Islandia y de su aislamiento melancólico, expuestos a todos los peligros, solos sobre el triste mar, acabo de decirle a Gauguin que como consecuencia de esas conversaciones íntimas se me había ocurrido la idea de pintar semejante cuadro, de tal modo que los marinos, a la vez niños y mártires, al verlo en la cabina de un barco de pescadores de Islandia, tendrían una sensación de mecimiento que les recordaría su propio canto de nodriza (...)

Estas telas me las imagino justamente entre las de los girasoles que de este modo forman lámparas o candelabros a su lado del mismo tamaño, y así el conjunto se compone de siete o nueve telas" (carta 574).

Pero además, al concebirla formando parte de un políptico flanqueada por los girasoles "como candelabros", Van Gogh le está confiriendo la categoría de una imagen casi religiosa. Con ella su adoración y añoranza por la figura de la madre -y de la mujer en general como madre dedicada al hogar y entregada al cuidado de sus hijos-, que permaneció inalterable a lo largo de toda su vida, alcanza su máxima definición pictórica. 43

\footnotetext{
42 Para Van Gogh los Roulin eran la pareja y la familia ideal. Retrató a Augustine Roulin, esposa del cartero Roulin, en diversas ocasiones. Primero realizó varias versiones con Marcelle, su tercera hija, recién nacida en brazos, y entre diciembre de 1888 y marzo de 1889 hasta cinco versiones del retrato que se conoce como La Berceuse, en el cual deja intuir la presencia de Marcelle por medio de la cuerda que sostiene su madre para mecer la cuna.

43 Sobre La Berceuse ver: ARIKAWA, H.: La Berceuse. An Interpretatión of Vincent van Gogh's Portraits. Annual Bulletin of The National Museum of Western Art, Tokio, 1981, págs. 31-75; SUND, Judy, "Van Gogh's Berceuse and the Sanctity of the Secular" en Van Gogh 100 por J. Masheck, Westport, Conn/London, 1996, págs. 205-225; BONNAT, Jean-Louis, "Les adresses d'un tablau. "La berceuse" (V. Van Gogh)". Psychanalyse a L'Universite, vol. 12, n 47, 1987, págs. 373-416.
} 